\title{
Evaluation of the Contribution of Deposited Precipitation
}

\author{
Jaroslav Fišák ${ }^{1}$ and Miroslav Tesař² \\ ${ }^{1}$ Institute of Atmospheric Physics, Academy of Sciences of the Czech Republic, Bočni II 1401, 14131 Prague 4, Czech Republic \\ ${ }^{2}$ Institute of Hydrodynamics, Academy of Sciences of the Czech Republic, Pod Pat'ankou 30/5, 16612 Prague 6, Czech Republic
}

Correspondence should be addressed to Miroslav Tesař; tesarihas@iol.cz

Received 3 July 2014; Accepted 3 November 2014

Academic Editor: Francisco J. Tapiador

Copyright (C 2015 J. Fišák and M. Tesař. This is an open access article distributed under the Creative Commons Attribution License, which permits unrestricted use, distribution, and reproduction in any medium, provided the original work is properly cited.

\begin{abstract}
Main topic of this study is evaluation of the contribution of deposited precipitation (DP) to the falling precipitation (FP) amount. An automatic device for DP weight measurement developed and produced at the Institute of Atmospheric Physics was used. The tipping bucket rain gauges were used for the FP measurement. Present paper summarizes the results of measurements of deposited and falling precipitation in three localities: Suchdol, Prague (capital of the Czech Republic), Poledník (Bohemian Forest), and Smĕdava (the Jizerské hory Mts.). Two later introduced stations are situated in the mountainous part of the Czech Republic. For each of mentioned stations the daily averages of the DP totals were determined by the values $0.074 \mathrm{~mm}$ for Suchdol, $0.112 \mathrm{~mm}$ for Poledník, and $0.103 \mathrm{~mm}$ for Smĕdava. Further the mean daily DP sums were evaluated for the days with the occurrence of this precipitation only by the values $0.136 \mathrm{~mm}, 0.276 \mathrm{~mm}$, and $0.289 \mathrm{~mm}$ for the stations Suchdol, Poledník, and Smĕdava, respectively. Obtained results were compared with the findings published in the literature. In each of the stations the ratio between the deposited and falling precipitation was determined as well. For the Suchdol this ratio reached 95.2\% in December 2013.
\end{abstract}

\section{Introduction}

Deposited precipitation, including dew, frozen dew, rime, and fog depositions, contributes a barely quantifiable volume of water to ecosystems. The amount of deposited precipitation from fog is typically estimated rather than measured and the liquid water content (LWC) of fog can be evaluated for the estimation as discussed by for example, Fišák et al. [1]. Recent studies have rarely measured the volume of deposited precipitation, focusing instead on the polluting substances present in the deposited precipitation. Such studies include Acker et al. [2], Aikawa et al. [3], Fišák and Řezáčová [4], and Fišák et al. [5]. Polluting substances present in the atmospheric boundary layer are deposited during precipitation events. Beysens et al. [6-8], Chiwa et al. [9], Clus et al. [10-12], and Galek et al. [13] have measured precipitation levels and assessed chemical pollution content. Chemical attributes of deposited precipitation in India are presented in Muselli et al. [14] and Sharan et al. [15], for example.

Deposited precipitation, especially dew, is evaluated in some studies, usually as the by-product of analyzing deposited precipitation pollution. Examples of such studies include Beysens et al. [7, 8] and Muselli et al. [16, 17], for sampling areas in France; Muselli et al. [14] and Mileta et al. [18], for Croatia; Jacobs et al. [19], for the central part of the Netherlands; Clus et al. [12], for Tahiti; and Galek et al. [13], for Poland.

The primary objective of the present study was to quantitatively evaluate the contribution of deposited precipitation to the total precipitation volume, rather than analyzing the chemical characteristics of deposited precipitation water. For this reason, we measured the precipitation volume but did not collect the precipitation water.

Recent studies of precipitation volumes have not included deposited precipitation, primarily due to the lack of regular measurements or estimations of deposited precipitation amounts. In this study, we evaluated the contribution of deposited precipitation at three sites, Suchdol, Poledník, and Smědava. The long-term measurement of the deposited precipitation amount has been running at the Suchdol, Prague locality only (since March 2011 till nowadays) with a few interruptions. 


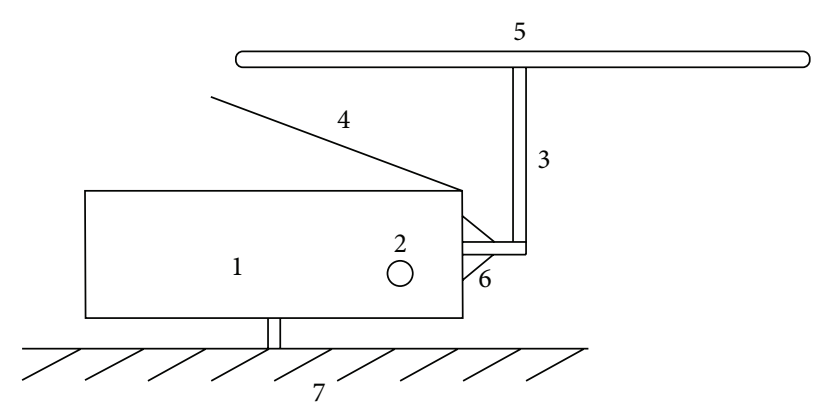

FIGURE 1: The scheme of the automatic device for deposited precipitation measurement (1: case with electronics, 2: connector, 3: holder, 4: thermal cover, 5: collecting board, 6: gasket cover, and 7: pedestal).

The other localities were equipped with the automatic instrument for the measurement of the deposited precipitation on the second half of 2013. These localities are represented by the mountainous stands Poledník and Smědava where the instrument is debarred from the operation due to a thick snow cover during the winter season.

\section{Materials and Methods}

2.1. Description of the Automatic Device. A device for weighing deposited precipitation has been constructed at the Institute of Atmospheric Physics in the Czech Republic. The device is schematically pictured in Figure 1, which shows the two main components: the electronics case and collecting board.

The case in which the electronics are contained (1) is attached to a pedestal (7) designed to provide sufficient stability for the device. The connector (2) is attached to the case and is designed to provide power to the electronic component and allow communication with the computer. The electronics case includes a thermally compensated tensiometric bridge and space for electronic connections. The bridge is connected via a low thermal conductivity holder to the catching board (5). The output of the holder from the case is protected from insects and dirt by a gasket cover. A thermal cover (4) above the electronics case protects the catching board from heat interference.

The catching board has an area of $0.2 \mathrm{~m}^{2}$ and is balanced with a water level during installation. More information about this automatic device and its measurement of deposited precipitation measurement is available in Fišák et al. [20]. Similar devices are also presented in Beysens et al. [6] and Muselli et al. [16]. The differences between these devices and instrument used for our purposes consist in their use. Instruments described in literature mentioned above are intended especially for the collection of the deposited precipitation samples while the device used by us was developed primarily for the continual measurement of the deposited precipitation.

2.2. Site Description. Dew measurements were provided at the "Station for Transport Processes and Soil Wetness Observation" of the Department of Water Resources, Faculty of
Agrobiology, Food and Natural Resources, Czech University of Life Sciences in Prague (DWR, FAFNR, CULS). This station is located on the University grounds along the northnorthwestern (NNW) edge of Prague, in the town district of Suchdol. Additional two stations were created by the Institute of Hydrodynamics of the Academy of Sciences of the Czech Republic at the mountainous headwater regions. The first of them-Poledník Mt. (1315 m a.s.l.)-lies in the south-western part of the Czech Republic in the cold climatic zone in the National Park of the Šmava Mts. (Bohemian Forest). The instrument is placed on the top of the Poledník Mt. The second one-Smédava Mt. (1083 $\mathrm{m}$ a.s.1.) - is located in the Landscape Protected Area of the Jizera Mountains in the northern Bohemia. This region represents a typical Central European temperate boreal zone with a large amount of precipitation and humid climate. The monitoring station was created on the north-eastern slope of the Smerdava Mt. at an elevation of $1000 \mathrm{~m}$ a.s.l. Figure 2 illustrates the localization of the experimental sites, while Figure 3 brings a view of the monitoring station on the Smědava Mt.

2.3. Methods of Evaluation. The experimental localities are equipped with the automatic meteorological stations and supplemented by the automatic instrument for the measurement of the weight of deposited precipitation (DP). The data on falling precipitation (FP), air temperature, air humidity, wind speed, and visibility were available. The evaluation of the weight of DP was worked out according to Fišák et al. [20]. The data from Suchdol, Prague locality, were used since March 2011 until the end of 2013. There are several interruptions in this data series caused by either necessary treatment of the instrument or power failures in the data sets. These interruptions are apparent in Table 1.

The experimental stands Poledník and Smědava were equipped with the instrument for the measurement of the weight of DP only at the second half of 2013 so that the data series are very short. They were involved into the elaboration especially from the reason that they represent the mountainous stations which can be used for at least partly comparison of the geographically different localities.

\section{Results}

3.1. Summarization of Data. The results of monitoring are summarized in tables, where are given data as follows:

(i) amount of DP $[\mathrm{mm}]$,

(ii) amount of FP [mm],

(iii) number of days with the DP occurrence (DDP),

(iv) number of days with the running measurement (DM).

For the purposes of analyses only the data series with the running measurement of both deposited and falling precipitation were used. Thus the cases with missing either the deposited or falling precipitation were eliminated. In the real practice the eliminated cases were caused due to the lack of DP measurement. 


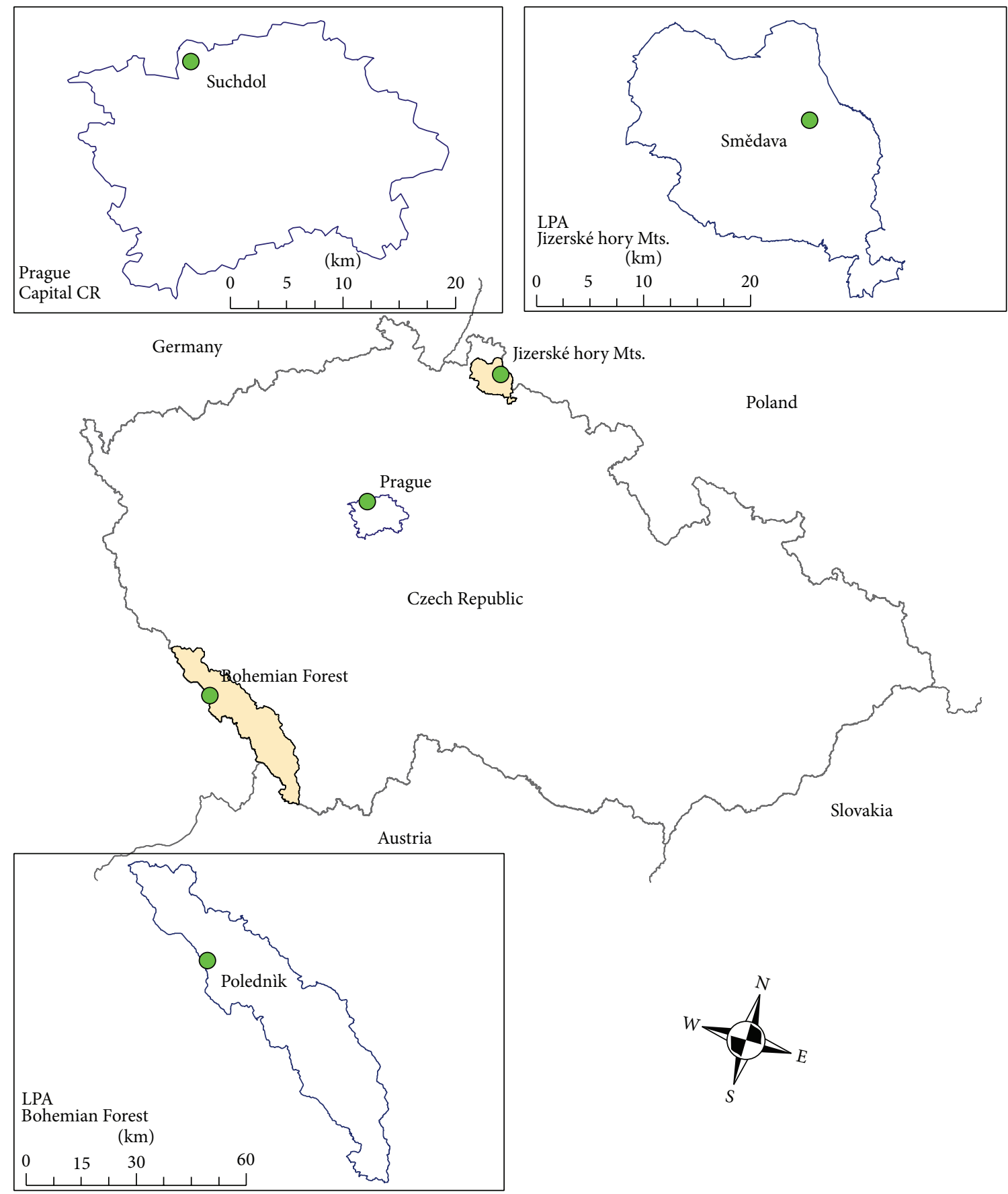

Figure 2: Localization of the experimental stands in the Czech Republic, Suchdol, Prague (capital of the Czech Republic), Smědava, Jizerské hory Mts. (Landscape Protected Area of the Jizerské hory Mts.), and Poledník, Bohemian Forest (Landscape Protected Area and National Park of the Šumava Mts.).

In order to be able to compare the time periods with a different length the following characteristics were chosen:

(i) amount of DP allotted for 1 day $\left[\mathrm{mm} \cdot \mathrm{day}^{-1}\right]$,

(ii) amount of DP allotted for 1 day with the occurrence of DP [mm.day ${ }^{-1}$ with DP],

(iii) amount of FP allotted for 1 day $\left[\mathrm{mm} \cdot\right.$ day $\left.^{-1}\right]$,

(iv) ratio of the DP and FP [\%].
Table 1 brings the above mentioned characteristics for the Suchdol, Prague locality, and Table 2 illustrates the same results for Poledník and Smědava stands.

3.2. The Contribution of Deposited Precipitation. There were a total of 827 days that were measured, with deposited precipitation observed on 446 of those days in station Suchdol, Prague. The results of these measurements are shown in 


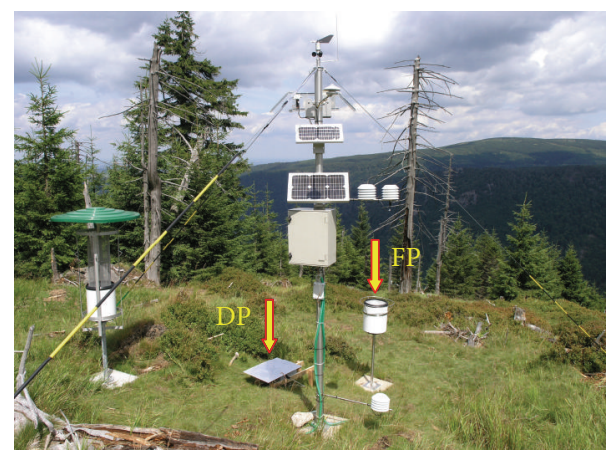

FIGURE 3: Meteorological station Smědava, Jizerské hory Mts. (DP: instrument for the deposited precipitation measurement, i.e., dew gauge; FP: instrument for the falling precipitation measurement, i.e., tipping bucket rain gauge).

Table 1. The total deposited precipitation amount has been $60.8 \mathrm{~mm}$ for the whole measured time period. In the same period the falling precipitation total equals $1197.6 \mathrm{~mm}$. That means the DP represented $5.1 \%$ of FP. The most significant contribution of DP appeared during the time period with a very low FP occurrence. There are a few examples in the course of time period of the measurement, for example, February 2012, when FP was $7.2 \mathrm{~mm}$ and DP was $1.9 \mathrm{~mm}$, that is, $26.4 \%$ of FP. As further example March 2012 can be taken, when $3.5 \mathrm{~mm}$ fell in the form of FP and $2.6 \mathrm{~mm}$ was measured as DP, that is, $74.3 \%$. In November 2013 this ratio was $47.6 \%$ when $4.2 \mathrm{~mm}$ fell as FP and $2.0 \mathrm{~mm}$ came as DP. The highest portion of DP (95.2\%) up to the present time was recorded in December 2013 when FP was $4.2 \mathrm{~mm}$ and DP was $4.0 \mathrm{~mm}$.

From the results in Table 1 it can be drawn that the highest portion of DP occurs during March and December (i.e., in the time period when both liquid and solid precipitation can appear in the climatic conditions in lower altitudes of the Czech Republic).

As it is described above the measurement at the Poledník station had proceeded since August 30, 2013, till October 15, 2013. There were 19 days with the DP occurrence during this time period as it is apparent in Table 2.

In this table it is also obvious that DP was $5.3 \mathrm{~mm}$ and FP was measured by the value of $190.1 \mathrm{~mm}$ for the evaluated time period. Thus the DP contribution was $2.8 \%$ of FP. For the Smédava locality, where the measurement had proceeded since August 17, 2013, till September 16, 2013, the amount of DP was $3.18 \mathrm{~mm}$ and FP equaled $183.2 \mathrm{~mm}$. In this case the DP contribution was $1.7 \%$ of FP. Due to the different durations of the measurement time periods, the monthly values cannot be considered characteristic results and thus are not included in Table 1. However, more representative values could be determined from the daily averages of DP for the entire sampling period and the daily averages of DP for days when DP occurred. Table 1 shows the daily average of DP for the entire sampling period was $0.074 \mathrm{~mm}$ (with a maximum of $0.124 \mathrm{~mm}$ in August) and the daily average for days when DP occurred was $0.136 \mathrm{~mm}$ (with a maximum of $0.225 \mathrm{~mm}$ in January).

The assessed daily average amount of DP was $0.112 \mathrm{~mm}$ and the average amount for the day with the occurrence of DP was $0.276 \mathrm{~mm}$ at the Poledník station. At the Smědava station the evaluated daily average amount of DP was $0.103 \mathrm{~mm}$ and the average amount for the day with the occurrence of DP was $0.289 \mathrm{~mm}$.

If a very short time period of the measurement is taken into account only the averages are presented as only preliminary results and no conclusion can be drawn based on them.

3.3. Comparison of Results with Other Studies. The results were compared with the results of previous studies. Unfortunately, the only data available for comparison were the deposited precipitation amounts for days when deposited precipitation occurred. The deposited precipitation amounts for calendar days were counted, whenever possible. We assume the reported number of samples (it is the same as number of days with DP occurrence) corresponds to the number of days when deposited precipitation occurred, and measurements were continuing during the entire period. The results are listed in Table 3. The data in this table prove that values for Suchdol, Prague locality, correspond with the data obtained from other stands. The values for the Poledník and Smědava localities are noticeably higher. This can be explained by two fundamental reasons: (i) these stands represent the mountainous regions with the influence of the altitude and DP amount; (ii) the results can be influenced by very short data sets.

Based on the studies, it is obvious that deposited precipitation can contribute approximately from $7 \mathrm{~mm}$ to $41 \mathrm{~mm}$ to annual precipitation, which is not an insignificant volume, especially in Europe. In our study, we found an amount of deposited precipitation nearing the higher limit. These results were achieved most likely because we were not interested in the chemical composition of the precipitation; thus, the measurements were performed using an automatic device and were not affected by any human factors.

\section{Conclusions}

Although measurements of deposited precipitation in the "Station for Transport Processes and Soil Wetness Observation" were conducted for only a relatively short period, the results are quite interesting. The contribution of deposited precipitation to the total precipitation amount was shown to be significant. The automatic device enabled measurements when temperatures were below $0^{\circ} \mathrm{C}$, which means solid deposited precipitation, such as white frost and frozen dew, was also measured. This ability allowed for observations of deposited precipitation in every season of the year.

At the Suchdol, Prague locality, the daily average amount of DP was $0.074 \mathrm{~mm}$ and maximum $0.102 \mathrm{~mm}$. The daily average amount of DP was $0.112 \mathrm{~mm}$ and maximum $0.145 \mathrm{~mm}$ at the Poledník locality while at the Smèdava locality the daily average amount of DP was $0.103 \mathrm{~mm}$ and maximum $0.112 \mathrm{~mm}$. These evaluated DP totals are the highest values that they have been recorded and published in literature up to the present time but it is necessary to take into account 
TABLE 1: Evaluation of precipitation amount in Suchdol, Prague locality.

\begin{tabular}{|c|c|c|c|c|c|c|c|c|c|c|c|c|c|c|}
\hline \multirow{2}{*}{ Year } & \multirow{2}{*}{ Characteristic } & \multicolumn{12}{|c|}{ Month } & \multirow{2}{*}{ Total } \\
\hline & & I. & II. & III. & IV. & V. & VI. & VII. & VIII. & IX. & $\mathrm{X}$. & XI. & XII. & \\
\hline \multirow{5}{*}{2011} & $\mathrm{DP}[\mathrm{mm}]$ & - & - & 1.5 & 1.4 & 2.2 & 1.3 & 2.0 & 4.7 & - & - & - & - & 13.1 \\
\hline & $\mathrm{FP}[\mathrm{mm}]$ & - & - & 25.2 & 20.6 & 34.6 & 57.1 & 114.4 & 65.1 & - & - & - & - & 317.4 \\
\hline & DDP & - & - & 23 & 20 & 22 & 13 & 19 & 26 & - & - & - & - & 123 \\
\hline & $\mathrm{DM}$ & - & - & 31 & 30 & 31 & 30 & 31 & 31 & - & - & - & - & 184 \\
\hline & DP/FP [\%] & - & - & 6.0 & 6.8 & 6.4 & 2.3 & 1.7 & 7.2 & - & - & - & - & 4.1 \\
\hline \multirow{5}{*}{2012} & $\mathrm{DP}[\mathrm{mm}]$ & 0.1 & 1.9 & 2.6 & 2.3 & 2.0 & 2.0 & 1.4 & 2.5 & 2.0 & 2.5 & 2.3 & 2.3 & 23.9 \\
\hline & $\mathrm{FP}[\mathrm{mm}]$ & 36.0 & 7.2 & 3.5 & 40.8 & 20.0 & 47.5 & 103.2 & 26.3 & 23.5 & 44.2 & 50.0 & 54.8 & 457.0 \\
\hline & DDP & 2 & 14 & 17 & 20 & 20 & 20 & 8 & 15 & 11 & 17 & 17 & 13 & 174 \\
\hline & $\mathrm{DM}$ & 12 & 23 & 31 & 30 & 31 & 30 & 15 & 23 & 18 & 31 & 30 & 31 & 305 \\
\hline & DP/FP [\%] & 0.3 & 26.4 & 74.3 & 5.6 & 10.0 & 4.2 & 1.4 & 9.5 & 8.5 & 5.7 & 4.6 & 4.2 & 5.2 \\
\hline \multirow{5}{*}{2013} & $\mathrm{DP}[\mathrm{mm}]$ & 1.7 & 1.6 & 1.5 & 1.5 & 1.0 & 1.9 & 2.0 & 1.1 & 1.9 & 3.6 & 2.0 & 4.0 & 23.8 \\
\hline & $\mathrm{FP}[\mathrm{mm}]$ & 44.6 & 41.2 & 18.5 & 21.1 & 95.5 & 30.9 & 67.1 & 17.1 & 35.3 & 43.5 & 4.2 & 4.2 & 423.2 \\
\hline & DDP & 6 & 7 & 11 & 10 & 9 & 15 & 15 & 7 & 15 & 21 & 11 & 22 & 149 \\
\hline & $\mathrm{DM}$ & 31 & 28 & 31 & 28 & 31 & 30 & 24 & 13 & 30 & 31 & 30 & 31 & 338 \\
\hline & DP/FP [\%] & 3.8 & 3.9 & 8.1 & 7.1 & 1.0 & 6.1 & 3.0 & 6.4 & 5.4 & 8.3 & 47.6 & 95.2 & 5.6 \\
\hline \multirow{5}{*}{ Total } & $\mathrm{DP}[\mathrm{mm}]$ & 1.8 & 3.5 & 5.6 & 5.2 & 5.2 & 5.2 & 5.4 & 8.3 & 3.9 & 6.1 & 4.3 & 6.3 & 60.8 \\
\hline & $\mathrm{FP}[\mathrm{mm}]$ & 80.6 & 48.4 & 47.2 & 82.5 & 150.1 & 135.5 & 285.1 & 108.5 & 58.8 & 87.7 & 54.2 & 59.0 & 1197.6 \\
\hline & DDP & 8 & 21 & 51 & 50 & 51 & 48 & 42 & 48 & 26 & 38 & 28 & 35 & 446 \\
\hline & $\mathrm{DM}$ & 43 & 51 & 93 & 88 & 93 & 90 & 70 & 67 & 48 & 62 & 60 & 62 & 827 \\
\hline & DP/FP [\%] & 2.2 & 7.2 & 11.9 & 6.3 & 3.5 & 3.8 & 1.9 & 7.6 & 6.6 & 7.0 & 7.9 & 10.7 & 5.1 \\
\hline \multirow{2}{*}{ DP } & [mm/per day] & 0.042 & 0.069 & 0.060 & 0.059 & 0.056 & 0.058 & 0.077 & 0.124 & 0.081 & 0.098 & 0.072 & 0.102 & 0.074 \\
\hline & [mm/per DP day] & 0.225 & 0.167 & 0.110 & 0.104 & 0.102 & 0.108 & 0.129 & 0.173 & 0.150 & 0.161 & 0.154 & 0.180 & 0.136 \\
\hline FP & {$[\mathrm{mm} /$ per day] } & 1.874 & 0.949 & 0.508 & 0.938 & 1.614 & 1.506 & 4.073 & 1.619 & 1.225 & 1.415 & 0.903 & 0.952 & 1.448 \\
\hline
\end{tabular}

DP: deposited precipitation amount.

FP: falling precipitation amount.

DDP: number of days with deposited precipitation.

DM: number of days with measurement.

TABLE 2: Evaluation of precipitation amount at the Poledník and Smědava localities (year 2013).

\begin{tabular}{|c|c|c|c|c|c|c|c|}
\hline \multirow{3}{*}{ Characteristic } & \multirow{2}{*}{\multicolumn{4}{|c|}{$\begin{array}{l}\text { Poledník } \\
\text { Month }\end{array}$}} & \multirow{2}{*}{\multicolumn{3}{|c|}{$\begin{array}{l}\text { Smědava } \\
\text { Month }\end{array}$}} \\
\hline & & & & & & & \\
\hline & VIII. & IX. & $\mathrm{X}$. & Total & VIII. & IX. & Total \\
\hline$\overline{\mathrm{DP}}[\mathrm{mm}]$ & 0.1 & 3.0 & 2.2 & 5.3 & 1.7 & 1.5 & 3.2 \\
\hline $\mathrm{FP}[\mathrm{mm}]$ & 0.3 & 137.7 & 52.1 & 190.1 & 19.6 & 163.6 & 183.2 \\
\hline DDP & 1 & 11 & 7 & 19 & 6 & 5 & 11 \\
\hline $\mathrm{DM}$ & 2 & 30 & 15 & 47 & 15 & 16 & 31 \\
\hline DP/FP [\%] & - & 2.2 & 4.2 & 2.7 & 8.7 & 0.9 & 1.7 \\
\hline \multicolumn{8}{|l|}{$\overline{\mathrm{DP}}$} \\
\hline Per day & 0.057 & 0.099 & 0.145 & 0.112 & 0.112 & 0.094 & 0.103 \\
\hline Per DP day & 0.113 & 0.269 & 0.311 & 0.276 & 0.281 & 0.299 & 0.289 \\
\hline \multicolumn{8}{|l|}{$\mathrm{FP}$} \\
\hline Per day & 0.150 & 4.590 & 3.473 & 4.045 & 1.307 & 10.225 & 5.910 \\
\hline
\end{tabular}

DP: deposited precipitation amount.

FP: falling precipitation amount.

DDP: number of days with deposited precipitation.

DM: number of days with measurement.

the mountainous situation of these localities as well as a very short time period of the measurement.

Also the comparison of the ratio DP/FP brings interesting results for the Suchdol, Prague locality. From this comparison it can be drawn that the highest values of DP/FP exist in the months with low totals of FP. For the whole analyzed time period the mean ratio DP/FP was 5.1\% at the Suchdol, Prague locality. Maximum ratio DP/FP (95.2\%) was calculated in December 2013 (value of DP was $4.0 \mathrm{~mm}$ while value of FP equaled $4.2 \mathrm{~mm}$ ). 
TABLE 3: Comparison of results of previous studies.

\begin{tabular}{|c|c|c|c|}
\hline \multirow{2}{*}{ Site } & \multicolumn{2}{|c|}{ Mean amount DP } & \multirow{2}{*}{ Source } \\
\hline & [mm/DP day] & {$[\mathrm{mm} /$ day $]$} & \\
\hline Brive-la-Gaillarde (France) & 0.115 & $0.086^{*}$ & Beysens et al. [7] \\
\hline \multirow{2}{*}{ Ajaccio (France) } & 0.120 & $0.062^{*}$ & Muselli et al. [16] \\
\hline & $\approx 0.106$ & n.d. & Muselli et al. [21] \\
\hline \multirow{2}{*}{ Komiza (Croatia) } & 0.080 & $0.020^{*}$ & Mileta et al. [18] \\
\hline & 0.108 & $0.020^{*}$ & Muselli et al. [14] \\
\hline \multirow{2}{*}{ Zadar (Croatia) } & 0.150 & $0.041^{*}$ & Mileta et al. [18] \\
\hline & 0.138 & $0.026^{*}$ & Muselli et al. [14] \\
\hline Central Netherlands & 0.100 & n.d. & Jacobs et al. [19] \\
\hline Tahiti & 0.068 & $0.068^{*}$ & Clus et al. [11] \\
\hline South-West Morocco & 0.106 & $0.052^{*}$ & Lekouch et al. [22] \\
\hline Wroclaw (Poland) & 0.103 & $0.049^{*}$ & Galek et al. [13] \\
\hline Sudetes (Poland) & 0.190 & $0.050^{*}$ & Galek et al. [13] \\
\hline Prague (Czech Republic) & 0.136 & 0.074 & This work \\
\hline Poledník (Czech Republic) & 0.276 & 0.112 & This work \\
\hline Smědava (Czech Republic) & 0.289 & 0.106 & This work \\
\hline
\end{tabular}

* Derived values (based on the assumptions given in publication). DP: deposited precipitation. n.d.: missing data.

If a very short time period of the data sets is taken into account only the average ratio DP/FP was determined for the Poledník and Smědava stations. This ratio has a value of $2.8 \%$ for the Poledník station and $1.7 \%$ for the Smédava stand. Because of a short time period of the measurement the evaluation of the maximum of a ratio DP/FP should not have any practical meaning.

If year-round validity of the derived daily averages of DP totals is supposed also for the stations with a short time period of the measurement, thus also for Poledník and Smèdava localities, it is possible to estimate the annual contribution of DP to annual precipitation total. In the case of Suchdol, Prague locality, this contribution represents $27 \mathrm{~mm}$, at the Poledník station the annual DP total could reach $40.9 \mathrm{~mm}$, and at the Smerdava locality this value equals $37.6 \mathrm{~mm}$. These amounts of water could be taken into account as not very important from hydrological point of view. But from the point of view of the total wet deposition and in light of the well known fact of the much higher pollutant concentrations in DP compared to FP the amount of DP attains much higher importance.

\section{Conflict of Interests}

The authors declare that there is no conflict of interests regarding the publication of this paper.

\section{Acknowledgments}

The results described in this paper were obtained with support of the GACR Project no. 205/09/1918. The additional support was provided by the Technology Agency of the Czech Republic (TA02021451).

\section{References}

[1] J. Fišák, D. Řezáčová, and J. Mattanen, "Calculated and measured values of liquid water content in clean and polluted environments," Studia Geophysica et Geodaetica, vol. 50, no. 1, pp. 121-130, 2006.

[2] K. Acker, S. Mertes, D. Möller, W. Wieprecht, R. Auel, and D. Kalaß, "Case study of cloud physical and chemical processes in low clouds at Mt. Brocken," Atmospheric Research, vol. 64, no. 1-4, pp. 41-51, 2002.

[3] M. Aikawa, T. Hiraki, M. Suzuki, M. Tamaki, and M. Kasahara, "Separate chemical characterizations of fog water, aerosol, and gas before, during, and after fog events near an industrialized area in Japan," Atmospheric Environment, vol. 41, no. 9, pp. 19501959, 2007.

[4] J. Fišák and D. Řezáčová, "Comparison between pollutant concentration in the samples of fog and rime water collected at Mt. Milešovka," Studia Geophysica et Geodaetica, vol. 45, no. 3, pp. 319-324, 2001.

[5] J. Fišák, D. Řezáčová, V. Weignerová, and M. Tesař, “Synoptic situations and pollutant concentrations in fog water samples from the Milešovka Mt," Studia Geophysica et Geodaetica, vol. 48, no. 2, pp. 469-481, 2004.

[6] D. Beysens, I. Milimouk, V. Nikolayev, M. Muselli, and J. Marcillat, "Using radiative cooling to condense atmospheric vapor: a study to improve water yield," Journal of Hydrology, vol. 276, no. 1-4, pp. 1-11, 2003.

[7] D. Beysens, C. Ohayon, M. Muselli, and O. Clus, "Chemical and biological characteristics of dew and rain water in an urban coastal area (Bordeaux, France)," Atmospheric Environment, vol. 40, no. 20, pp. 3710-3723, 2006.

[8] D. Beysens, M. Muselli, I. Milimouk et al., "Application of passive radiative cooling for dew condensation," Energy, vol. 31, no. 13, pp. 1967-1979, 2006.

[9] M. Chiwa, T. Miyake, N. Kimura, and H. Sakugawa, "Organic acids and aldehydes in throughfall and dew in a Japanese pine 
forest," Journal of Environmental Quality, vol. 37, no. 6, pp. 23972402, 2008.

[10] O. Clus, I. Lekouch, M. Muselli, I. Milimouk-Melnytchouk, and D. Beysens, "Dew, fog and rain water collectors in a village of S-Morocco (Idouasskssou)," Desalination and Water Treatment, vol. 51, no. 19-21, pp. 4235-4238, 2013.

[11] O. Clus, P. Ortega, M. Muselli, I. Milimouk, and D. Beysens, "Study of dew water collection in humid tropical islands," Journal of Hydrology, vol. 361, no. 1-2, pp. 159-171, 2008.

[12] O. Clus, J. Ouazzani, M. Muselli, V. S. Nikolayev, G. Sharan, and D. Beysens, "Comparison of various radiation-cooled dew condensers using computational fluid dynamics," Desalination, vol. 249, no. 2, pp. 707-712, 2009.

[13] G. Galek, M. Sobik, M. Blaś, Z. Polkowska, and K. CichalaKamrowska, "Dew formation and chemistry near a motorway in Poland," Pure and Applied Geophysics, vol. 169, no. 5-6, pp. 1053-1066, 2012.

[14] M. Muselli, D. Beysens, M. Mileta, and I. Milimouk, "Dew and rain water collection in the Dalmatian Coast, Croatia," Atmospheric Research, vol. 92, no. 4, pp. 455-463, 2009.

[15] G. Sharan, O. Clus, S. Singh, M. Muselli, and D. Beysens, "A very large dew and rain ridge collector in the Kutch area (Gujarat, India)," Journal of Hydrology, vol. 405, no. 1-2, pp. 171-181, 2011.

[16] M. Muselli, D. Beysens, J. Marcillat, I. Milimouk, T. Nilsson, and A. Louche, "Dew water collector for potable water in Ajaccio (Corsica Island, France)," Atmospheric Research, vol. 64, no. 14, pp. 297-312, 2002.

[17] M. Muselli, D. Beysens, and E. Soyeux, "Is dew water potable? Chemical and biological analyses of dew water in Ajaccio (Corsica Island, France)," Journal of Environmental Quality, vol. 35, no. 5, pp. 1812-1817, 2006.

[18] M. Mileta, M. Muselli, D. Beysens et al., "Comparison of dew yields in four Mediterranean sites: similarities and differences," in Proceedings of the 3rd International Conference of Fog, Fog Collection and Dew, Cape Town, South Africa, October 2004, E2.

[19] A. F. G. Jacobs, B. G. Heusinkveld, and S. M. Berkowicz, "Passive dew collection in a grassland area, The Netherlands," Atmospheric Research, vol. 87, no. 3-4, pp. 377-385, 2008.

[20] J. Fišák, J. Chum, J. Vojta, and K. Bartůňková, "Automatic monitoring of the amount of deposited precipitation," Journal of Hydrometeorology, vol. 14, no. 2, pp. 670-676, 2013.

[21] M. Muselli, D. Beysens, and I. Milimouk, "A comparative study of two large radiative dew water condensers," Journal of Arid Environments, vol. 64, no. 1, pp. 54-76, 2006.

[22] I. Lekouch, M. Mileta, M. Muselli et al., "Comparative chemical analysis of dew and rain water," Atmospheric Research, vol. 95, no. 2-3, pp. 224-234, 2010. 

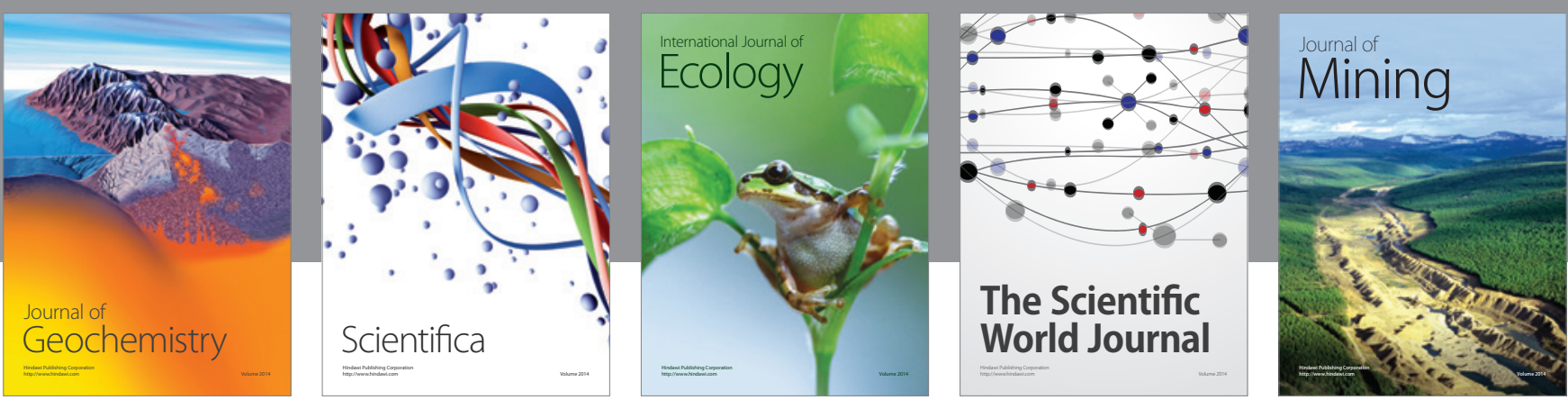

The Scientific World Journal
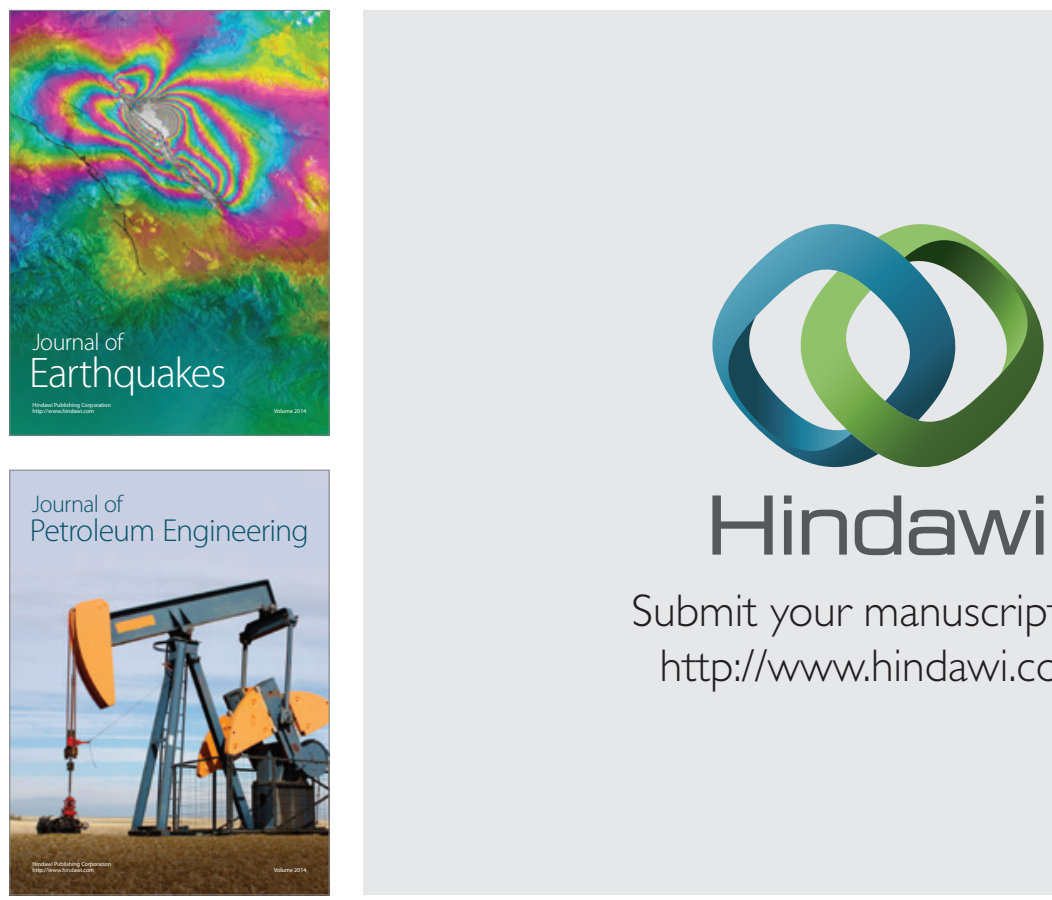

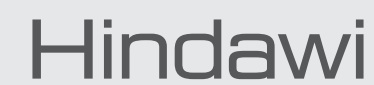

Submit your manuscripts at

http://www.hindawi.com
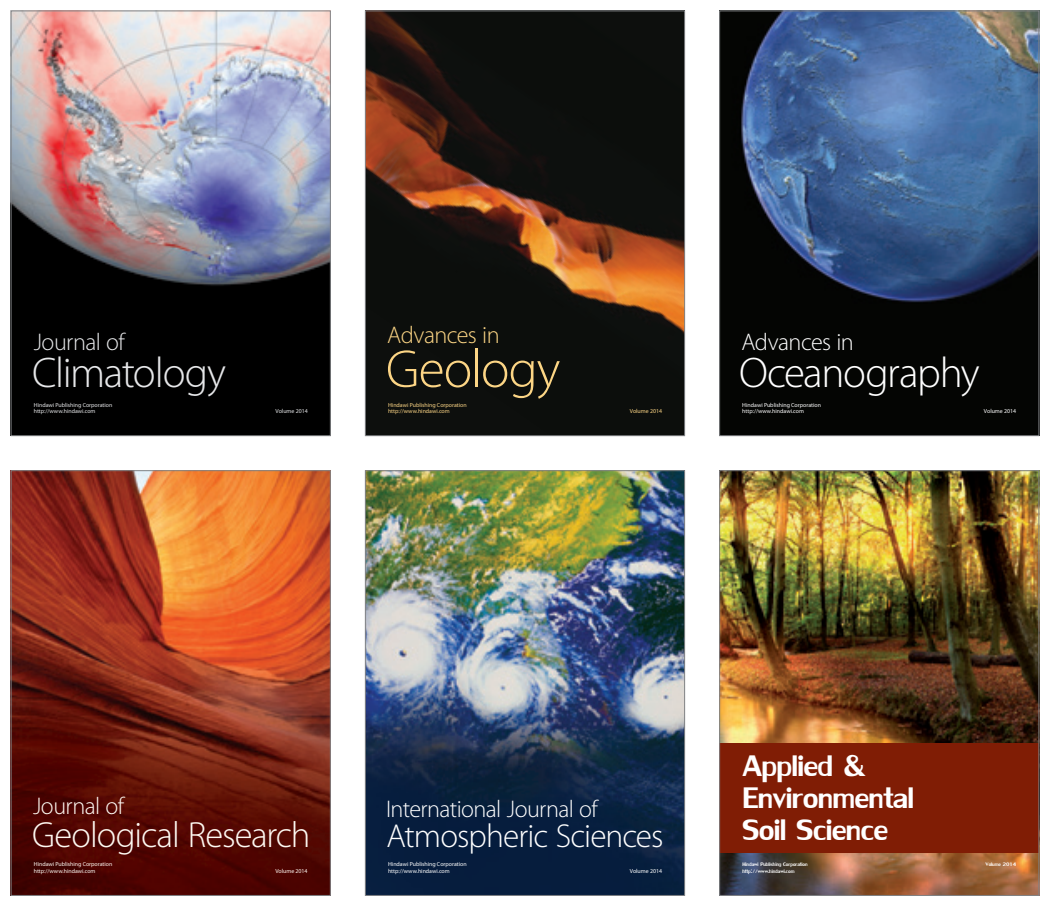
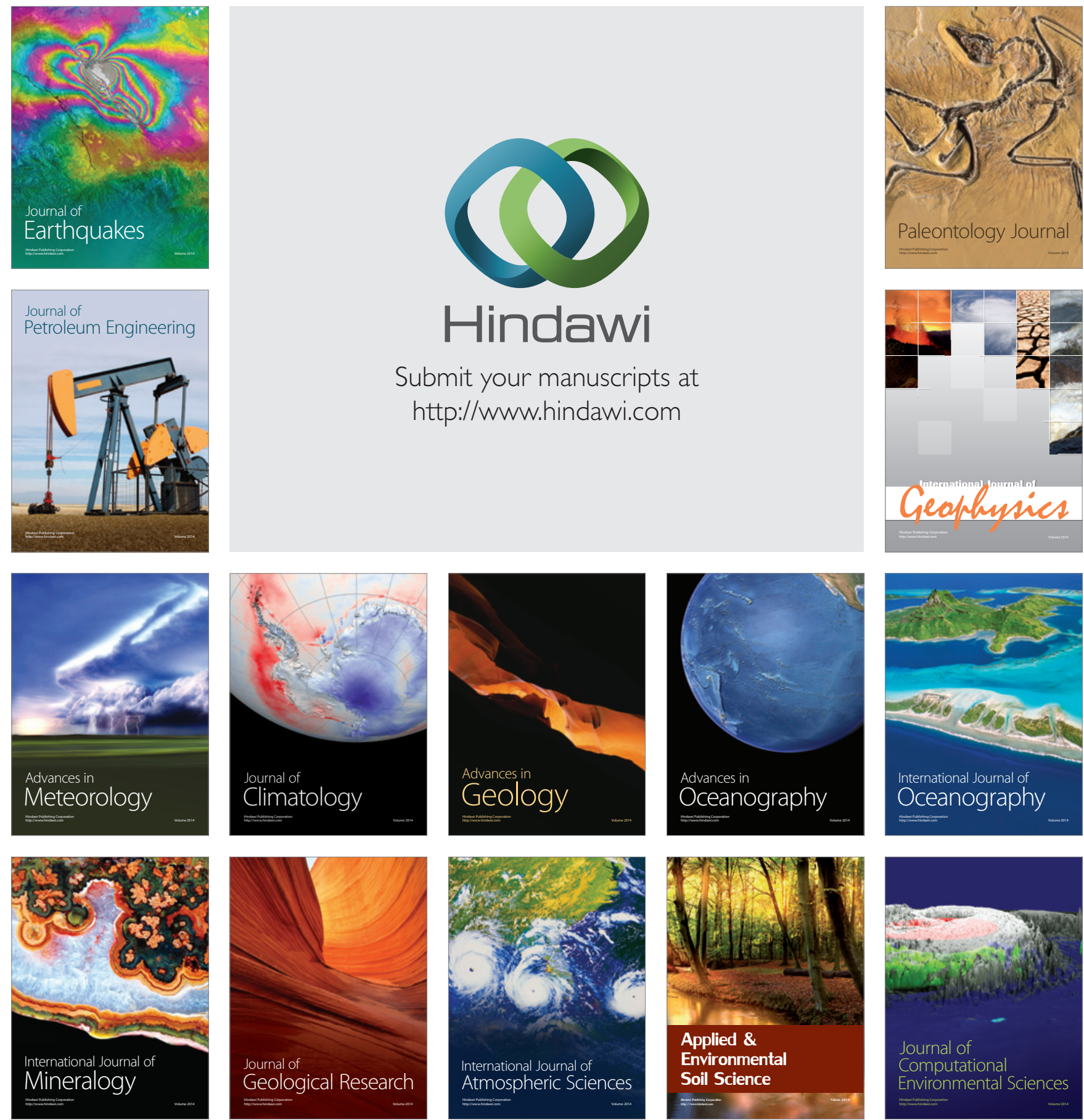